\title{
易感染患者に対する抗生物質投与期間の適正化のための監視
}

\author{
樋口和子, * 久保智美，向井栄治，二宮昌樹，塚本豊久，森田修之
}

\section{Surveillance of Reasonable Period of Antibiotic Administration to Compromised Hosts}

\author{
Kazuko Higuchi, Tomomi Kubo, Eiji Mukai, Masaki NinOMIYA, \\ Toyohisa TSUKAMOTO, and Shushi MoRITA \\ Department of Pharmacy, University Hospital, Faculty of Medicine, Kagawa Medical University, \\ 1750-1, Ikenobe, Miki-cho, Kita-gun, Kagawa 761-0793, Japan
}

(Received June 5, 2001; Accepted November 9, 2001)

\begin{abstract}
For the purpose of prevention of hospital-acquired infection caused by antibiotic-resistant bacteria, we examined a method to establish an appropriate time period for the administration of antibiotics to compromised hosts. Using these antibiotics we monitored patients who received instruction about the drug regimen in the Blood and Respiratory Diseases Department ward. We monitored a) third-generation cephalospolins, b) Imipenem/Cilastatin, and c) antibiotics used against methicillin-resistant Staphylococcus aureus. When the antibiotics were administered over 14 days, pharmacists notified physicians of the current duration of administration using a confirmation form, and confirmed their future administration schedule. We examined the antibiotic usage regimen of all the patients in this ward before and after the confirmation form was adopted. Patients given the same antibiotics within 14 days significantly increased in percentage from $82 \%$ to $91 \%$ after the confirmation form was adopted $(p<0.05)$. The median duration of antibiotic administration decreased from 7 days to 5 days. The case with antibiotic administration for the longest duration was a patient with leukemia who received vancomycin for 116 days after adoption of the confirmation form. This patient died 4 days after his antibiotic was changed. Only $16 \%$ of the patients administered antibiotics in this ward were monitored for the duration of antibiotic administration after adoption of the confirmation form. When the pharmacists positively provided physicians with information on some patients concerning the prolongation of antibiotic administration, the number of patients administered antibiotics for less than 14 days significantly increased throughout this ward without interfering with the treatment of patients who required long-term administration of antibiotics.
\end{abstract}

Key words_ _ reasonable period of antibiotic administration; prevention of antibiotic-resistant bacteria; hospital pharmacist; prevention of hospital-acquired infection; compromised host; confirmation form

\section{緒言}

近年，医療現場で最も問題になっている感染症は 多剂耐性菌による院内感染である。医療の進歩に伴 い易感染患者が増加し, 弱毒菌による感染症を起こ し，抗生物質の投与が耐性菌を増加させている。従 来，院内感染防止のために，看護婦を中心に手洗い や環境整備などの対策が取り組まれてきた。しか し, 耐性菌対策の場合，菌の伝播を抑制する方法よ りも，抗生物質の適正使用を実施し耐性菌を発生さ せない方法が有効である. ${ }^{1)}$

具体的な方法としては，抗生物質使用ガイドライ ンの作成, 抗生物質の種類や使用方法の制限, 医療

香川医科大学医学部附属病院薬剂部

e-mail: higuchi@kms.ac.jp
従事者の教育などが考えられる．アメリカでは疾病 対策センター（CDC）が院内感染対策のガイドラ インを作成している。また，臨床薬剤師が，医師の 抗生物質の処方設計支援やコンサルテーションを行 い，抗生物質が使用基準に適合しているかをチェッ クしている. ${ }^{2)}$

本邦では外科医の倉本ら ${ }^{3)}$ が，消化器外科病棟で 抗生物質の術後投与を中心に適正使用を試みた結 果, 使用量の削減とメチシリン耐性黄色ブドウ球菌 (以下, MRSA)/ブドウ球菌比が 90 年度 $50 \%$ から 95 年度 $0 \%$ に低下したと報告している。 また，薬剤 師が検查部と共同で抗生物質の使用状況と臨床分離 菌との関連性を調査した報告や, ${ }^{4-6)}$ バンコマイシ ン等の血中濃度測定が望ましい抗生物質の薬物動態 を解析して最適投与計画を支援したとの報告7)があ 
る.

耐性菌対策の場合，感受性菌に耐性を獲得させな いことが重要であり，抗生物質の適正使用における 薬の専門家としての薬剤師への期待は大きい。特 に，セフェム系第三世代などの広域で抗菌力が強く MRSA 発生との間に関連性が指摘4,8-10)されている 抗生物質（以下，広域抗生物質）の適正使用は重要 で，同一抗生物質の長期漫然投与は防止すべきと考 えられる。しかし，薬剤師が広域抗生物質の適正使 用に関与し，効果を挙げたという報告は見あたらな い.

著者らは，本邦でもアメリカと同様に薬剤師が医 師の処方決定に関与し，抗生物質の適正使用を推進 することが可能か検討することは重要であると考え た。そこで，易感染患者が多く，広域抗生物質を繁 用している血液・呼吸器内科病棟を中心に, 広域及 び MRSA 用抗生物質の長期投与症例について治療 予定などを確認した。確認の実施前後で，抗生物質 の使用状況を調査し処方への影響について検討した ので報告する.

\section{調 査と方法}

\section{1.「抗生物質継続使用確認書」の記載内容}

本院では 1999 年 6 月より，同一抗生物質の長期投 与患者を対象に感受性試験の結果や治療予定を確認 する目的で「抗生物質継続使用確認書」（以下，確 認書，Fig. 1）の提出依頼を行っている．確認書の 記載内容を開始時より 2001 年 1 月迄の期間を対象 に調査した。確認書は対象抗生物質の投与日数が 15 日以上の患者について，薬剤師が主治医に提出 を依頼した。 15 日を確認書の対象とする投与日数 の基準とした理由は，重症感染症での標準的投与日 数が 14 日とされているためである. ${ }^{11-13)}$

抗生物質は広域抗生物質, 及び MRSA 用抗生物 質のうち注射剂を対象とした。患者は，最も易感染 患者の多い血液・呼吸器内科病棟における服薬指導 患者のうち広域抗生物質または MRSA 用抗生物質 投与患者, 及び全病棟の入院患者のうちテイコプラ ニン投与患者を対象とした。

2. 確認書導入前と導入後の血液. 呼吸器内科病 棟での抗生物質の使用状況血液・呼吸器内科病 棟に入院中の患者のうち, 確認書開始前の 1999 年 3-4 月，開始後の同年 8-9 月及び 9 力月経過後の
2000 年 3-4 月中に抗生物質の投与があった全患 者，それぞれ 40 名， 38 名，42 名を対象とした。 2000 年 3-4 月を調査したのは, 確認書の長期的効 果の確認，及び感染症の季節変動により抗生物質の 使用状況が変化する可能性について評価するためで ある。

調査は，注射薬処方せん及び返納伝票に基づき， 抗生物質名，投与量，投与日数について行った。投 与日数は，当該投与が調查対象月の前又は後にまた がる場合も含めて調査した。 1 つの抗生物質の計画 的投与，抗生物質の併用，変更，再投与もそれぞれ 1 症例とした。同一抗生物質の投与中に休薬期間が ある場合，1 日の休薬は腎機能障害等による減量な ど用量調節のためと考えて一連の投与とみなし 1 症 例としたが，2 日以上は別の症例とした。抗生物質 の併用状況については同一日の朝と夕で抗生物質を 切り替える場合があるので，2 日以上同一日に併用 した場合を併用とした。

併せて，調査期間における調査対象の患者背景を 比較するために，病院情報システムより患者の性 別，年齢，病名を調査した。また，確認書は服薬指 導患者を対象患者としたため，薬剂管理指導料請求 患者一覧より患者への服薬指導の実施状況を調査 し，対象患者の割合を調査した。

3. 統計処理 Stat View ver5.0 (日本語 Macintosh 版, SAS Institute Inc.) による MannWhitney の $\mathrm{U}$ 検定，カイ 2 乗検定を用い， $p<0.05$ を有意とした。

\section{調 査 結 果}

1. 確認書の記載内容 調査期間中に確認書の 提出を依頼した患者数は 10 名ですべて提出され た. 病棟は血液・呼吸器内科 8 名, 呼吸器・消化器 外科, 心臓・消化器外科がそれぞれ 1 名であった。 抗生物質はバンコマイシン 3 名, テイコプラニン, セフタジジム，セフォゾプランがそれぞれ 2 名であ つた。病名は癌（前癌状態を含む）9名，心臓手術 後 1 名であった. 確認後の抗生物質投与は, 継続 5 名，中止 3 名，変更 2 名であった． 8 名の患者の主 治医は確認を希望し，2名はどちらとも言えないと 回答した。なお，3名の患者は同一主治医ですべて 確認を希望すると回答した.

2. 確認書導入前と導入後の血液·呼吸器内科病 
科

先生

平成年月日

メチシリン耐性黄色ブドウ球菌（M R S A）による感染を防止するためには、消毒の微底と『抗生物 質の適正使用』が重要とされています。そこで、MR S A感染対策特別委員会と薬㸝部で協力して『抗生 物質の適正使用』を推進しようと計画しています。つきましては、同一抗生物質の使用が 2 週間を超えて いる患者に「抗生物質継続使用確認書」を送らせて頂いています。大変㧍忙しい中誠に恐縮ですが、ご記 入の上、近日中に薬夙部 注射室まで提出して下さい。

「抗生物質継続使用確認書」

※四角内について番号に○を付け空欄を記入して下さい。それ以外峐薬剂師が記入します。

【患者情報】

入院病棟 : 東・西病棟階

患者氏名：

病名：

【抗生物質】

抗生物質名：タゴシッド、バンコマイシン、ハベカシン、

その他:

投薬期間：日旦開始（日是在、日)

投与量：1回勧（g、mg、 $) \times 1$ 日 回

\section{【感受性試験の結果】}

菌名：

(検出、疑い)

検查依頼状況：検查を実施（結果：）、依頼中、未実施

【治療予定】

1. 継続して使用します

(理由と予定期間 :

2. 他の抗生物質に変更します（変更抗生物質名：

3. 抗生物質の投与を中止します

\section{【「確認書」に対する先生のご意見】}

1. 抗生物質の投薬期間が長期に渡る場合は確認して下さい

2. どちらとも言えません

3. 投薬期間は把握しているので確認する必要はありません

4. その他（具体的に記入：

お問い合わせ先 : 薬剂部（記入薬剤師

内線

Fig. 1. Confirmation Form for Continuous Use of Antibiotics

棟での抗生物質の使用状況血液・呼吸器内科病 棟では，1999 年 3-4 月 40名，同年 8-9 月 38名, 2000 年 3-4 月 42 名の患者に抗生物質が投与され, 症例数は，それぞれ，182 症例， 141 症例， 140 症 例であった．患者背景を Table 1 に示した．各調査 期間における患者背景に差は認められなかった。使
用抗生物質と投与量を Table 2 に示した。投与量は 静菌的抗生物質ミノサイクリンの 2 症例のみが常用 量を超過していた。各調查期間の使用抗生物質は成 分別に比較すると異なっていたが $(p<0.05$, カイ 2 乗検定)，系統別で評価すると差は認められなか つた．投与日数を Table 3 に示した．全投与例に占 
Table 1. Background of Patients before and after Confirmation Form

\begin{tabular}{|c|c|c|c|c|}
\hline & 1999 年 3-4 月 & 1999 年 8-9 月 & 2000 年 3-4 月 & 統計 $d)$ \\
\hline 患者数 & 40 & 38 & 42 & \\
\hline \multicolumn{5}{|l|}{ 性別 } \\
\hline 男 & 30 & 21 & 26 & \multirow[t]{2}{*}{ N.S. } \\
\hline 女 & 10 & 17 & 16 & \\
\hline 年齢 $a)$ & $60 \pm 15$ & $58 \pm 16$ & $57 \pm 17$ & N.S. \\
\hline \multicolumn{5}{|l|}{ 疾患 ${ }^{b)}$} \\
\hline 白血病 & 13 & 11 & 9 & \multirow[t]{10}{*}{ N.S. } \\
\hline 肺癌 & 9 & 10 & 11 & \\
\hline リンパ腫 & 7 & 8 & 9 & \\
\hline 骨䯙異形成症候群 & 3 & 2 & 3 & \\
\hline 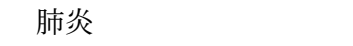 & 2 & 0 & 1 & \\
\hline 慢性/悪性関節リウマチ & 2 & 0 & 1 & \\
\hline 多発性骨髄腫 & 1 & 0 & 2 & \\
\hline 強皮症 ～ & 1 & 1 & 2 & \\
\hline 再生不良性貧血 & 1 & 2 & 0 & \\
\hline その他 & 4 & 4 & 4 & \\
\hline \multicolumn{5}{|l|}{ 服薬指導c) } \\
\hline 有 & $21(52)$ & $20(53)$ & $23(55)$ & \multirow[t]{2}{*}{ N.S. } \\
\hline 無 & $19(48)$ & $18(47)$ & $19(45)$ & \\
\hline
\end{tabular}

める 14 日以内の投与例の割合は，1999 年 3-4 月 82 \%，1999 年 8-9 月 89\%，2000 年 3-4 月 91\%であり 有意に増加した $(p<0.05$, カイ 2 乗検定 $)$. しか し，平均投与日数，併用薬品数，のべ投与薬品数に は有意な差は認められなかつた。投与日数の分布を Fig. 2 に示した. 確認書後は経時的に 14 日以内へ 分布する傾向が認められ，中央值は 1999 年 3-4 月， 1999 年 8-9 月とも 7 日に対し，2000 年 3-4 月は 5 日であった。一方，少数例存在する長期投与症例は 減少しなかった。最長の 116 日投与の症例は 2000 年 3-4 月の白血病の緩解，再発を繰り返した患者で あつた．確認書を依頼した時点では抗癌剤に反応せ ず免疫力は低下しており，抗生物質の投与で感染症 （多発性肝脾膿瘍）を抑制していた。さらに免疫力 が低下しバンコマイシン（116 日投与），メロペネ ム（107 日投与）からアルベカシン, セフォゾプラ ンに変更になり，変更 4 日後に敗血症で死亡した。 なお，バンコマイシンが確認書の対象となり，主治 医からはStaphylococcus epidermidis を検出し, バ ンコマイシンに感受性があり, 肝脾膿瘍形成のため 長期投与が必要との回答を得た.

投与日数 14 日を基準に症例を分けて服薬指導の
有無との関係を Table 4 に示したが，一定の傾向は なく関連性は認められなかった。

\section{考察}

広域抗生物質の使用が而性菌を増加させ, ${ }^{8-10)}$ 耐 性菌による院内感染が重大な医療問題になったこと の反省より，術後抗生物質投与の臨床評価に関する ガイドライン14)が作成されるなど抗生物質の適正使 用が推進されている。その結果，セフェム系第 3 世 代の使用が減少し，第 1 世代の使用が増加するなど の効果が現れている.15)しかしながら，依然として セフェム系第 3 世代など広域抗生物質の使用は多 く，適正使用は重要な課題である。

今回の調査では, 血液・呼吸器内科病棟での広域 及び MRSA 用抗生物質の投与日数 15 日以上の患 者に主眼をおいて治療予定や感受性を確認する方法 を採用した。当該病棟では, 造血器や呼吸器癌の患 者に骨髄移植や癌化学療法が日常的に行われている ことから，本院で最も免疫力の低下した患者が多く 入院し，広域抗生物質が繁用されている。また，当 該病棟は薬剤管理指導業務実施病棟である。薬剤師 は業務上，抗生物質の投与状況を薬歴に記載してお 
Table 2. Antibiotics Used and Daily Dose of Antibiotics before and after Confirmation Form

\begin{tabular}{|c|c|c|c|c|c|c|c|c|}
\hline \multirow{2}{*}{ 系 統 } & \multirow{2}{*}{ 商品名 } & \multirow{2}{*}{1 日常用量 } & \multirow{2}{*}{$\begin{array}{l}\text { 実施前 } \\
\text { 症例数 }\end{array}$} & （1999 年 3-4 月） & \multirow{2}{*}{$\frac{\text { 実施直後 }}{\text { 症例数 }}$} & （1999 年 8-9 月） & \multicolumn{2}{|c|}{ 実施 9 ケ月後 (2000 年 3-4 月) } \\
\hline & & & & 1 日投与量 & & 1 日投与量 & 症例数 & 1 日投与量 \\
\hline \multirow[t]{4}{*}{ ペニシリン } & $\begin{array}{l}\text { スルバクタム/ } \\
\text { アンピシリシ }\end{array}$ & $3-6 \mathrm{~g}$ & 4 & $6 \mathrm{~g}$ & 1 & $3-6 \mathrm{~g}$ & 0 & - \\
\hline & ピペラシリン & $2-8 \mathrm{~g}$ & 4 & $1-8 \mathrm{~g}$ & 4 & $2-4 \mathrm{~g}$ & 3 & $4-8 \mathrm{~g}$ \\
\hline & $\begin{array}{l}\text { ベンジルペニ } \\
\text { シリシ }\end{array}$ & 60-240 万単位 & 0 & - & 2 & 200 万単位 & 1 & 100-200 万単位 \\
\hline & 小 計 & & 8 & & 7 & & 4 & \\
\hline $\begin{array}{l}\text { セフェム系 } \\
\text { 第一世代 }\end{array}$ & セファゾリン & $1-5 \mathrm{~g}$ & 0 & - & 3 & $1-4 \mathrm{~g}$ & 3 & $1-4 \mathrm{~g}$ \\
\hline \multirow{3}{*}{ 第二エ世允系 } & セフォチアム & $0.5-4 \mathrm{~g}$ & 14 & $1-4 \mathrm{~g}$ & 9 & $1-2 \mathrm{~g}$ & 4 & $1-2 \mathrm{~g}$ \\
\hline & セフメタゾー & $1-4 \mathrm{~g}$ & 0 & - & 0 & - & 1 & $2 \mathrm{~g}$ \\
\hline & 小 計 & & 14 & & 9 & & 5 & \\
\hline \multirow[t]{7}{*}{$\begin{array}{l}\text { セフェム系 } \\
\text { 第三世代 } a)\end{array}$} & $\begin{array}{l}\text { スルバクタム/ } \\
\text { セフォペラゾ } \\
\text { ン }\end{array}$ & $1-4 \mathrm{~g}$ & 0 & - & 4 & $1-2 \mathrm{~g}$ & 2 & $1-2 \mathrm{~g}$ \\
\hline & セフェピム & $1-4 \mathrm{~g}$ & 5 & $2-4 \mathrm{~g}$ & 1 & $2 \mathrm{~g}$ & 1 & $2 \mathrm{~g}$ \\
\hline & セフォゾプラ & $1-4 \mathrm{~g}$ & 15 & $2-4 \mathrm{~g}$ & 5 & $2-4 \mathrm{~g}$ & 15 & $1-4 \mathrm{~g}$ \\
\hline & セフタジジム & $1-4 \mathrm{~g}$ & 23 & $1-4 \mathrm{~g}$ & 20 & $1-4 \mathrm{~g}$ & 16 & $1-4 \mathrm{~g}$ \\
\hline & セフピロム & $1-4 \mathrm{~g}$ & 4 & $1-4 \mathrm{~g}$ & 4 & $1-4 \mathrm{~g}$ & 1 & $1-4 \mathrm{~g}$ \\
\hline & ラタモキセフ & $1-4 \mathrm{~g}$ & 1 & $1-3 \mathrm{~g}$ & 0 & - & 0 & - \\
\hline & 小 計 & & 48 & & 34 & & 35 & \\
\hline \multirow[t]{4}{*}{$\begin{array}{l}\text { カルバペネ } \\
\text { ム系 }\end{array}$} & $\begin{array}{l}\text { イミペネム/シ } \\
\text { ラスタチンal }\end{array}$ & $0.5-2 \mathrm{~g}$ & 22 & $0.5-2 \mathrm{~g}$ & 10 & $0.5-2 \mathrm{~g}$ & 24 & $0.5-2 \mathrm{~g}$ \\
\hline & $\begin{array}{l}\text { パニペネム/ベ } \\
\text { タミプロシ }\end{array}$ & $1-2 \mathrm{~g}$ & 11 & $0.5-2 \mathrm{~g}$ & 13 & $1-2 \mathrm{~g}$ & 9 & $0.5-2 \mathrm{~g}$ \\
\hline & メロペネム & $0.5-2 \mathrm{~g}$ & 8 & $0.5-2 \mathrm{~g}$ & 9 & $1-2 \mathrm{~g}$ & 4 & $1-2 \mathrm{~g}$ \\
\hline & 小 計 & & 41 & & 32 & & 37 & \\
\hline \multirow{6}{*}{$\begin{array}{l}\text { アミノグリ } \\
\text { コシド系 }\end{array}$} & アミカシン & $100-400 \mathrm{mg}$ & 30 & $200-400 \mathrm{mg}$ & 14 & $200-400 \mathrm{mg}$ & 23 & $100-400 \mathrm{mg}$ \\
\hline & アルベカシンa) & $150-200 \mathrm{mg}$ & 2 & $200 \mathrm{mg}$ & 0 & - & 0 & - \\
\hline & イセパマイシ & $400 \mathrm{mg}$ & 13 & $200-400 \mathrm{mg}$ & 9 & $200-400 \mathrm{mg}$ & 5 & $400 \mathrm{mg}$ \\
\hline & ゲンタマイシ & $80-120 \mathrm{mg}$ & 1 & $40-80 \mathrm{mg}$ & 1 & $40 \mathrm{mg}$ & 0 & - \\
\hline & トブラマイシ & $120-180 \mathrm{mg}$ & 0 & - & 10 & $90-180 \mathrm{mg}$ & 6 & $90-180 \mathrm{mg}$ \\
\hline & 小 計 & & 46 & & 34 & & 34 & \\
\hline $\begin{array}{l}\text { テトラサイ } \\
\text { クリン系 }\end{array}$ & ミノサイクリ & $100-200 \mathrm{mg}$ & 3 & $100-200 \mathrm{mg}$ & 5 & $100-400 \mathrm{mg}^{b)}$ & 7 & $\left.200-300 \mathrm{mg}^{b}\right)$ \\
\hline \multirow[t]{3}{*}{$\begin{array}{l}\text { グリコペプ } \\
\text { チド系 } a)\end{array}$} & テイコプラニ & $200-800 \mathrm{mg}$ & 1 & $400 \mathrm{mg}$ & 0 & - & 0 & - \\
\hline & $\begin{array}{l}\text { バンコマイシ } \\
\text { ン }\end{array}$ & $2 \mathrm{~g}$ & 15 & $0.4-2 \mathrm{~g}$ & 9 & $0.5-2 \mathrm{~g}$ & 9 & $0.5-2 \mathrm{~g}$ \\
\hline & 小 計 & & 16 & & 9 & & 9 & \\
\hline \multirow[t]{4}{*}{ その他 } & $\begin{array}{l}\text { クリンダマイ } \\
\text { ジン }\end{array}$ & $600-2400 \mathrm{mg}$ & 4 & $150-2400 \mathrm{mg}$ & 3 & $1200-2400 \mathrm{mg}$ & 4 & $600-2400 \mathrm{mg}$ \\
\hline & ホスホマイシ & $2-4 \mathrm{~g}$ & 2 & $1-2 \mathrm{~g}$ & 5 & $2-4 \mathrm{~g}$ & 2 & $4 \mathrm{~g}$ \\
\hline & 小 計 & & 6 & & 8 & & 6 & \\
\hline & 合 計 & & 182 & & 141 & & 140 & \\
\hline
\end{tabular}

a)「確認書」の対象となる抗生物質．症例数全体に占める割合は 1999 年 3-4 月 $36 \% ， 1999$ 年 8-9 月 30\%，2000 年 3-4 月 31\%。b) 1 症例において 1 日常用量超過. 
Table 3. Period of Administration and Number of Antibiotics before and after Confirmation Form

\begin{tabular}{|c|c|c|c|c|}
\hline & 1999 年 3-4 月 & 1999 年 8-9 月 & 2000 年 3-4 月 & 統計c) \\
\hline \multicolumn{5}{|l|}{ 投与日数 } \\
\hline 平均投与日数 ${ }^{a)}$ & $8.8 \pm 6.8$ & $8.2 \pm 6.4$ & $9.2 \pm 14$ & N.S. \\
\hline 最大投与日数 & 38 & 42 & 116 & - \\
\hline 14 日以下の症例数 ${ }^{b)}$ & $149(82)$ & $125(89)$ & $127(91)$ & \multirow{2}{*}{$p<0.05$} \\
\hline 15 日以上の症例数 ${ }^{b)}$ & $33(18)$ & $16(11)$ & 13 ( 9) & \\
\hline \multicolumn{5}{|l|}{ 投与薬品数 } \\
\hline 平均併用薬品数 ${ }^{a)}$ & $1.8 \pm 0.6$ & $1.8 \pm 0.7$ & $1.8 \pm 0.6$ & N.S. \\
\hline 最大併用薬品数 & 3 & 3 & 3 & - \\
\hline 平均のべ投与薬品数 $\left.{ }^{a}\right)$ & $3.2 \pm 2.2$ & $2.9 \pm 1.8$ & $2.7 \pm 1.7$ & N.S. \\
\hline 最大のべ投与薬品数 & 10 & 7 & 8 & - \\
\hline
\end{tabular}

Table 4. Comparison of Period of Administration of Antibiotics with and without Instructions about Drug Regimen before and after Confirmation Form

\begin{tabular}{|c|c|c|c|c|}
\hline \multirow{2}{*}{ 服薬指導 } & \multicolumn{2}{|c|}{ 投与日数 $\leqq 14$ 日 } & \multicolumn{2}{|c|}{ 投与日数 $\geqq 15$ 日 } \\
\hline & 有 & 無 & 有 & 無 \\
\hline 1999 年 3-4 月 & $84(46)$ & $65(36)$ & $16(9)$ & $17(9)$ \\
\hline 1999 年 8-9 月 & $58(41)$ & $67(48)$ & $14(10)$ & $2(1)$ \\
\hline 2000 年 3-4 月 & $75(54)$ & $52(37)$ & $7(5)$ & $6(4)$ \\
\hline
\end{tabular}

注釈：数字は症例数，( )内は各症例数が当該調查期間の症例数全 体に占める\%。

り，患者情報が容易に入手可能であり，薬剤師と医 師との連繋が確立している．これらのことから，薬 剤師が薬剤管理指導業務の一環として，抗生物質の 適正使用に関与するモデルとなりうるとの判断から 当該病棟を選択した。

セフェム系第 3 世代, イミペネム/シラスタチン は広域抗生物質で耐性菌の発生に関連が指摘されて いるため選択した。バンコマイシン，アルベカシ ン，テイコプラニンは MRSA 感染症の治療に用い るので選択した。特に, テイコプラニンは MRSA 用新規抗生物質であり, 新規に耐性菌感染症の治療 に使用する抗生物質を監視する方法の検討に適して いるとの理由で全病棟を対象とした。

抗生物質の適正使用を推進する方法としては，ガ イドラインの作成と使用制限との 2 通りが考えられ る。CDC は「バンコマイシン耐性菌の伝播防止に 関する勧告」16)など多くのガイドラインを作成して インターネットで公開している．本院でも院内感染 予防マニュアルに抗生物質の使用基準と適正使用の
項目を設けている.ガイドラインが効果を挙げるた めには，医師側に積極的な利用の意志が必要であ る. 先述のバンコマイシンのガイドラインの存在も 関わらず，バンコマイシン耐性腸球菌（VRE）が 多く検出され，ガイドラインから逸脱した使用が 33 - $65 \%$ 存在する. ${ }^{17-19)}$ ガイドラインの遵守のた めに, 感染症専門医や薬剤師により, バンコマイシ ンの使用を制限しているとの報告がある. ${ }^{20-21)}$ 特 定の抗生物質の使用制限は，効率的に使用を減少さ せると考えられる。しかしながら，広域及び MRSA 用抗生物質の使用を無条件に制限すること は治療の妨害になる可能性がある。

実際, 著者らが今回調査の対象とした血液・呼吸 器内科病棟では, 広域抗生物質が繁用されており, MRSA 用抗生物質の使用も多く, 患者は造血器癌 や呼吸器癌の易感染患者が中心であった。これらの 患者は，しばしば深在性真菌症を伴う重症感染症に 罹患し致命的となるため, 一般的に抗生物質及び抗 真菌剤の予防的投与が行われる. ${ }^{22}$ 同一患者におい ても，発熱した場合は感染症に対する治療的投与に なり，術後の感染予防投与と異なり明確な区別は困 難である。したがって，使用制限の実施に際して は，易感染患者の感染症治療に対する使用を厳密に 除外する必要があると考えられた。最長のバンコマ イシン 116 日投与の患者は免疫力が低下しており，

S. epidermidis を検出し, バンコマイシン感受性で あった。 バンコマイシンの適応は本邦では MRSA のみであるが， CDC ガイドライン16)では $\beta$-ラク夕 ム剂耐性グラム陽性菌による重症感染症の治療を適 

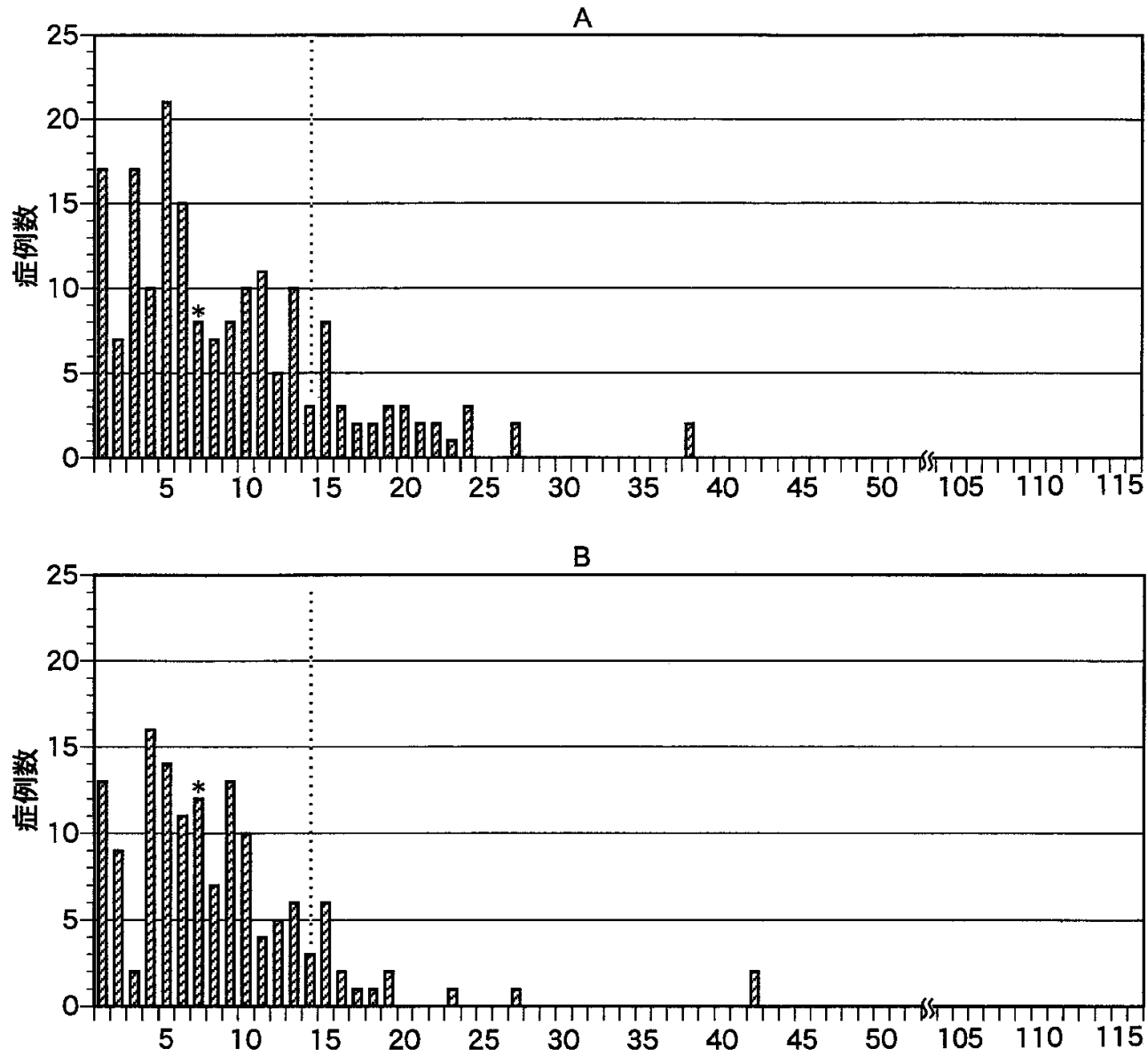

C

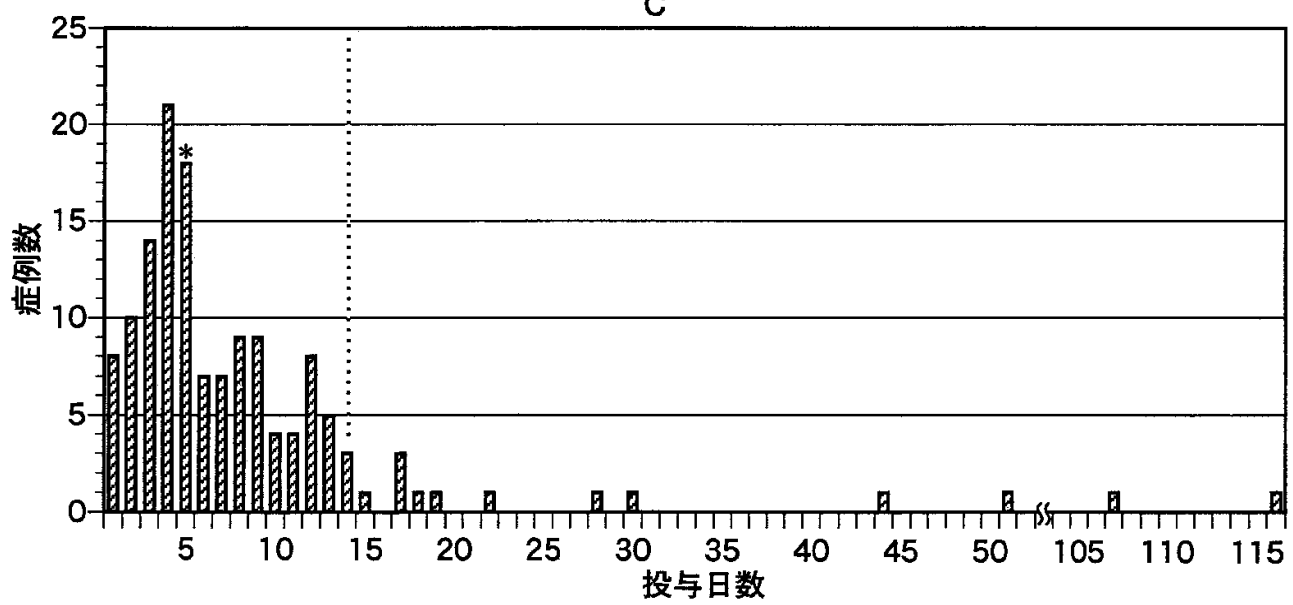

Fig. 2. Distribution of Days of Use of Antibiotics before and after Confirmation Form A: 1999.3-4, B: 1999.8-9, C: 2000.3-4, ...: day14, *: Median duration.

切で容認できるとしている．また，S. epidermidis のヒトでの病原性は弱いが, 敗血症や心内膜炎の原 因菌となる。ブドウ球菌の薬剤感受性パターンは似 通っているが，黄色ブドウ球菌に比べ而性パターン は多様性に富む. ${ }^{23)}$ したがって，抗生物質の適正使 用には患者背景や対象疾患の特性を考慮し，適正化
の方法について診療科と密接に協議する必要がある. 易感染患者の多い大学病院では感染症専門医や薬 剤師の育成と配置が特に必要である。すでにアメリ カにおいてはケンタッキー大学メディカルセン ター2)などで，薬剤師による抗生物質の適正使用が 組織的に実施されている。 また Lawton ら 24)による 
と集中治療部を対象とした 47 病院のアンケートの 結果，抗生物質の処方時には回答医師の $70 \%$ が感 染症専門医に，66\%が薬剤師に相談すると回答して いる. 抗生物質処方ガイドラインが調査病院の 70 \%で作成され，抗生物質の使用制限は $40 \%$ に過ぎ ない.

今回, 血液 - 呼吸器内科病棟において実施した方 法は，抗生物質の長期投与症例に限って，薬剤師が 医師に対し能動的に投与日数に関する情報を提供す る方法である。 その結果, 医師は薬剤師の情報を活 用し, その後も情報の提供を希望した. 当該病棟で は, 服薬指導未実施者や対象外の抗生物質を含む抗 生物質投与全体で, 投与日数の中央值が 7 日から 5 日に減少し (Fig. 2)，14 日以内の投与症例の割合 が $82 \%$ から $91 \%$ と有意に増加した（Table 3)。こ のことは，1999 年 8-9 月の服薬指導実施患者の割 合が $53 \%$ (Table 1), 確認書の対象となる抗生物 質の投与が 30\%（Table 2）であり，したがって確 認書を依頼するために監視された抗生物質の投与は 全体の $16 \%$ に過ぎないことを考えれば驚くべきこ とといえる。効果は経時的に緩徐に現れており (Fig. 2)，一部の患者において一部の抗生物質を対 象に実施した確認書の効果が抗生物質全体の使用に 拡大するには時間を要すると考えられた，患者背景 や抗生物質の系統別使用状況に差がないことより (Tables 1, 2)，季節による感染症の違いはなかった と考えられた。 したがつて，投与が長期化している という情報を積極的に提供する方法は，一部の症例 を対象に実施した場合においても, 感染症治療全体 を妨げることなく，不適切な長期投与を減少させる 優れた方法であると考えられた。病棟薬剤師の関与 については, 今回は投与日数の確認に留まつたが, 今後は疾患や起炎菌など個々の患者背景に基づき, 適正な抗生物質の選択と使用について医師の処方を 支援できることが望ましい。

今回の調查結果によると服薬指導の有無が確認書 の対象か否かを決定しているにもかかわらず，直接 的に投与日数を 14 日以内に偏らせた原因とは考え られなかった（Table 4)。確認書の実施は，診療科 と協力して院内感染予防マニュアルに抗生物質適正 使用の項目を追加，術後抗生物質の適正使用に関す る講演会の開催，イントラネットによる抗生物質の 使用方法に関する情報提供など，一連の抗生物質適
正使用に関する取り組みの一環として行われた。こ れらの取り組みも確認書と併行して実施されたが, 抗生物質の使用状況は投与日数の中央值が減少し, 14 日以内の投与が増加した以外に変化は認められ なかった．ただし，抗生物質に関する啓蒙活動を継 続的に実施すること, また, 薬剤管理指導業務を通 じて薬剤師と医師が日常的にかつ緊密に連携するこ とにより，医師は抗生物質全体に対する関心を高 め, 薬剂師から積極的に提供された投与日数情報を 臨床に活用するという意志決定を行つたと考えられ た. Shojania ら ${ }^{25)}$ はバンコマイシンについて, コ ンピュータ入力時に CDC ガイドラインを表示する ことにより，使用が減少したことを報告している． 全般的な啓蒙活動による知識や意識の向上に加え て, 患者個別の治療に即した積極的な情報提供が適 正使用に活用されやすいと考えられる.

今後, 病院全体ですべての抗生物質を対象に実施 するには, 病棟薬剤師の活躍に期待するとともに, 本院で稼働予定の注射オーダで処方時にチェックし たり，適正使用に関する情報を積極的に提供する方 法が有効かつ効率的であると考えている. また, 適 正使用推進による効果について, 抗生物質の使用動 向の変化や投与の短期化, 而性菌の減少, 感受性の 改善などについて, 定量的に評価することが必要で あると考えている。

\section{REFERENCES}

1) Lipsitch M., Bergstrorm C. T., Levin B. R., Proc. Natl. Acad. Sci. U. S. A., 97, 1938-1943 (2000).

2) Tsubaki T., Iga T., J. Jpn. Soci. Hosp. Pharm., 30, 443-450 (1994).

3) Kuramoto S., Kizu J., Yamamoto K., Kaminishi M., Oohara T., Antibiotics \& Chemotherapy, 15, 599-605 (1999).

4) Kawasaki H., Kanmera S., Ichikawa M., Hirakata Y., Kaku M., Kamihara S., Jpn. J. Hosp. Pharm., 22, 111-118 (1996) .

5) Hashimoto H., Kitamura O., Muramatsu R., Sano Y., Akaike Y., Goto T., Jpn. J. Hosp. Pharm., 18, 153-163 (1992).

6) Nagai K., Ohta S., Ohkubo Y., Atobe O., Zenda H., Kawakami Y., Jpn. J. Hosp. Pharm., 18, 282-287 (1992).

7) Higuchi S., Matsuyama K., Miyazaki T., 
"Dispensing of Information Using the Operating System "Windows," Jiho, Tokyo, 1999, pp. 186-217.

8) Konno M., SAISHIN IGAKU, 44, 2544-2553 (1989) .

9) Konno M., "All about MRSA Infection," Revised Edition, Medicine and Drug Journal, Osaka, 1993, pp. 36-67.

10) Tokue Y., Shoji S., Satoh K., Watanabe A., Motomiya M., Antimicrob. Agents Chemother., 36, 6-9 (1992).

11) Kawai M., Oizumi A., Hara Y., Nozaki S., Yamamoto Y., Jpn. J. Acute Medicine, 23, 403-405 (1999).

12) Tanaka H., Shimazaki S., Jpn. J. Acute Medicine, 23, 407-412 (1999).

13) Shinozawa Y., Ota Y., Ito N., Sato T., Jpn. J. Acute Medicine, 23, 477-479 (1999).

14) Committee for Establishment of Method of Clinical Estimation and Committee for Antibiotic Prophylaxis in Surgical Procedure of the Japanese Society of Chemotherapy, Jpn. J. Chemotherapy, 45, 553-641 (1997).

15) Higuchi K., Tsukamoto T., Nakano M., Antibiotics \& Chemotherapy, 10, 2334-2342 (1994).
16) Hospital Infection Control Practices Advisory Commitee, MMWR, 44, 1-13 (1995).

17) Morgan A. S., Brennan P. J., Fishman N. O., Ann. Pharmacother., 31, 970-973 (1997).

18) Johnson S. V., Hoey L. L., Vance B. K., Pharmacotherapy, 15, 579-585 (1995).

19) Evans M. E., Kortas K. J., Infect. Control Hosp. Epidemiol., 17, 356-359 (1996).

20) Cassandra E. B., John P., William H., Am. J. Health-Syst. Pharm., 54, 1893-1897 (1997).

21) Belliveau P. P., Rothman A. L., Maday C. E., Am. J. Health-Syst. Pharm., 53, 1570-1575 (1996)

22) Hiramatsu K., "Theory and Practice of Treatment for Infection with Resistant Bacteria," Medicine and Drug Journal, Tokyo, 1998, pp. 157-161.

23) Soudou H., "Medical Syndromes of Infectious Diseases I," Nipponrinshosha Co., Ltd., Osaka, 1999, pp. 245-247.

24) Lawton R. M., Fridkin S. K., Gaynes R. P., McGrowan J. E. Jr., Infect. Control Hosp. Epidemiol., 21, 256-259 (2000).

25) Shojania K. G., Yokoe D., Platt R., Fiskio J., Ma'luf N., Bates D. W., J. Am. Med. Info. Assoc., 5, 554-562 (1998). 